\title{
Frederich Manfred: The Quest of the Independent Writer
}

DELBERT E. WYLDER

In May of 1979, the National Endowment for the Arts announced a new program-Senior Fellowships for Literature-which will result in a few one-time grants to individuals "who have made an extraordinary contribution to American literature over a lifetime of creative work." These fellowships, however, are not to be awarded to "those whose work has had great commercial success." Frederick Manfred, the Iowa-born author of 18 novels, ${ }^{1}$ two volumes of short stories, and one book of poems, seems to fit neatly into these requirements. Born on a farm near Doon, Iowa, in 1912, just six years after the birth of Robert Penn Warren in the small town of Guthrie, Kentucky, Manfred has devoted his life to writing and has made an outstanding contribution to literature in America. His production has been large in volume and significance; yet, he has not received either the financial success or the general acclaim of the Kentuckian. The list of accomplishments-and awards-on the back cover of Warren's latest volume of extraordinarily fine poetry, Now and Then, is overwhelmingly impressive. As more than one individual must have already noted, he has little left to win but the Nobel Prize for Literature. On the other hand, American literary committees and organizations, with the exception of the Western Literature Association, have been more than reluctant to recognize the merit of Frederick Manfred. It should also be stated that the academic community as a whole has given little recognition to Frederick Manfred and his works, again with the exception of those scholars interested specifically in Western American literature.

This is not to suggest that the world is out of kilter and that the

1 Nineteen novels is the correct number if Wanderlust (the revised trilogy including The Primitive, The Brother, and The Giant) is considered as a separate work. 
Eastern publishing establishment has once more failed to recognize a Western writer, nor is it to denigrate in any way the accomplishments of Robert Penn Warren. It is to suggest, however, that both careers have developed along different lines, with different interests, and with different visions, and that both writers have contributed much over their lifetimes of creative work. Manfred would be the last to complain of Warren's awards and fame, nor is he, himself, impatient. What is important to Manfred is his art, though, like any human being, he could not help wanting some recognition for it.

Manfred and Warren have lived quite different careers. Warren left Kentucky for Vanderbilt University, one of the more prestigious universities in the South, and then went on to receive a master's degree from the University of California. He did further graduate work at Yale University and was a Rhodes Scholar at Oxford. For much of his life, he has been associated with the academic community as a teacher of literature and creative writing. To the contrary, and in contrariness, Manfred enrolled in tiny Calvin College, in Grand Rapids, Michigan, a school supported by the Christian Reformed Church. By the time he had graduated, in 1934, he had not only lost his Christian orthodox beliefs, he had also lost any interest he might have had in teaching. During the Depression years of 1934-37, he hitchhiked around the country, ending up in Minnesota as a sportswriter for the Minneapolis Journal. From 1940 to 1942, he battled tuberculosis in a sanatorium. In 1942, recovered, he joined the staff of Modern Medicine before becoming an assistant campaign manager in Hubert Humphrey's unsuccessful bid to become mayor of Minneapolis. He continued to work on a novel-the dust-bowl novel The Golden Bowl -and its publication and his credentials won him a University of Minnesota Regional Writing Fellowship. From then on, writing has been his life and his livelihood, and his tendency has been to write from his native area-his Siouxland. In 1960, he was able to move to his house, Blue Mound, north of Luverne, Minnesota. He was home. For the most part, he has maintained his distance from the academic community. He spent one year, 1949, as writer-in-residence at Macalester College, and recently he has had an arrangement with the University of South Dakota to teach creative writing-as a writer notquite-in-residence, since he drives back and forth from Luverne. He has, on numerous occasions, appeared as guest speaker or to give readings at writing conferences in colleges and universities, often with little or no pay, and he regularly attends the annual meeting of the Western Literature Association, a group he finds both receptive and amenable. For the most part, however, he shuns academic gath- 
erings and spends little time with New York publishers. He is more content to be writing and working in his home place. His traditional and emotional ties are with the people and the land of his region; thus critics have generally considered him a regionalist.

In a sense, Manfred is a regionalist, since most of his novels and short stories are set in the Dakotas, or Minnesota, or Iowa. But he is a regionalist only in that sense. Unlike a Herbert Quick, for example, his themes transcend the region. More like Faulkner, he has attempted to limit his fictional exploration of the human condition to that area he knows best and to the people whose lives and traditions he knows best. And, unfortunately, there has not been a Midwestern Renascence in which he might have been "discovered." Few people think of Fitzgerald, a fellow Minnesotan, or Hemingway from Illinois, as midwestern writers. Furthermore, Frederick Manfred is a "maverick." Alan Swallow appropriately included him in a 1959 essay called "The Mavericks,"2 and Joseph M. Flora explained the term quite succinctly in his Western Writers Series Frederick Manfred.

The mavericks are serious writers who have pursued their themes without much recognition from the Eastern press, partly, Swallow felt, because the Eastern press has not understood the Western themes or techniques or has been too contemptuous to make the effort. ${ }^{3}$

But even to many Western critics, Manfred remains a maverick, primarily because he simply is one. Manfred reads critics, he listens to them, he has close friends who are critics, and he probably wouldn't even mind if one of his children married one. However, he will no more listen to a critic tell him how to write than he will listen to an editor who tries to make changes in his manuscripts. Manfred has his own voice, and he has his own concept of structure. For the most part, the little critical evaluation that has been done on Manfred has not been descriptive, it has been comparative. Critics have, for the most part, expected him to adjust to the dominant techniques and structures of the time. His differences from these expectations are seen as faults. Such a position is easy to take, particularly with some of the earlier novels. But as Manfred continues to publish, he makes little or no effort to correct these "faults," and it is becoming more and more apparent that Frederick Manfred's growth will be on his own terms, and that it is, indeed, growth. Manfred's last three novels, and es-

2 Alan Swallow, “The Mavericks," Critique: Studies in Modern Fiction, 2 (Winter 1959), pp. 88-92. Reprinted in An Editor's Essays of Two Decades (Seattle and Denver: Experiment Press, 1962), pp. 353-57.

3 Joseph M. Flora, Frederick Manfred (Boise: Boise State University Press, 1974), p. 5. 
pecially the last two, should convince the critics that this growth should be recognized, and that Manfred's voice deserves to be heard.

Perhaps the first critical articles to bring Manfred's works to the attention of the "literary establishment" (rather than the book reviewers) were two articles by John R. Milton, now a colleague of Manfred, but then a professor and chairman at Jamestown College in North Dakota. The first was published in College English in 1957;4 the second was published, in 1958, in Ray B. West's Western Review at The University of Iowa. ${ }^{5}$ In that "Examination of New Writers" essay, Milton discussed The Golden Bowl (1944), Boy Almighty (1945), This Is the Year (1947), The Chokecherry Tree (1948), The Primitive (1949), The Brother (1950), The Giant (1951), Lord Grizzly (1954), and Morning Red (1956), and added a "postscript" on Manfred's novel based on the Johnson County War, Riders of Judgment (1957). Milton, using The Golden Bowl as a base, discusses Manfred's concept of the "long view" which, he concedes, at least appears in, although is not necessarily central to, all of Manfred's novels. The main character, Maury, Milton asserts, learns "the long view, the lesson of the land: hope is based on the roots of tradition, on brotherhood, and on the necessity of continuing the species."' He also suggests that, in Manfred's attempt to present the "full truth," the novelist has a tendency to provide literal transcriptions of the real world at the expense of the artistic concept of economy. Milton believes that "an overwhelming mass of detailed material tends to smother artistry."7

In discussing the trilogy Wanderlust (consisting of The Primitive, The Brother, and The Giant), Milton charges that it

suffers from a lack of selectivity, from personal prejudices, from moralizing, from uncontrolled excursions into the bypaths of autobiography, from an inconsistent tone, and from a childish ineptness in some matters of taste. ${ }^{8}$

Furthermore, in Milton's opinion, Manfred's

love of "things," his themes, and his uncontrolled passion for life all contribute to his frequent lack of conciseness, to his apparent lack of

4 John R. Milton, "Voice from Siouxland: Frederick Feikema Manfred," College English, 19 (December 1957), pp. 104-11.

5 John R. Milton, "Frederick Feikema Manfred," Western Review, 22 (Spring 1958), pp. 181-99. It should be noted that, by this time, Manfred had legally changed his named to Frederick Manfred and no longer used the pen name of "Feike Feikema."

6 Ibid., p. 182.

7 Ibid., p. 184.

8 Ibid., p. 187. 
concern for artisic craftsmanship. What he must leam, above all else, is his proper relationship to his reader. ${ }^{9}$

Though most of these conments seem derogatory, Milton treats Manfred and his works with respect, and he sees a promising future for the writer if Manfred can successfully blend his heart and his craft and can show some artistic selectivity and restraint.

To some degree, Joseph M. Flora's Western Writers Series Frederick Manfred elaborates on some of the same problems in Manfred's fiction, although this critical pamphlet is less negative than Milton's article. In one short passage, for example, Flora, discussing Morning Red, is concerned with structure, selectivity, craftsmanship, and taste:

The counter pointing of plots is not the major difficulty, nor is the problem even necessarily the great number of characters. The stumbling block is that Manfred suggests that some characters are going to be more important than they are. The reader gets too much detail about characters who do not matter. There is also too much specificity -for one example, in menus-a carryover from the autobiographical trilogy. Too, Manfred has seldom refrained from presenting the homely realities of any bodily functions, and in Morning Red he presents those realities at the expense of the tale. 10

Flora includes, in his discussion, the novels written between Riders of Judgment and Milk of Wolves, which had not then been published: Conquering Horse (1959), Scarlet Plume (1964), The Man Who Looked Like the Prince of Wales (1965), King of Spades (1966), Eden Prairie (1968), and many of the short stories, as well as the short novels in Arrow of Love (1961). An interesting task, then, is to look at the most recent publications of Manfred's to see whether he has indeed improved in artistry and taste.

For a reader coming upon Manfred's work for the first time, the answer may well be "No." Particularly for a critic who has been schooled in Percy Lubbock or in "the modern novel" based on an almost classical control of structure, symbol, and langauge, the answer may still be a rather vehement "No." Manfred is not a Hemingway nor a Fitzgerald-that is not his temperament. His sensitivity is basically rural rather than urban, close to the earth rather than sophisticated, and definitely not cosmopolitan. His literary tradition has derived from the Greeks, from the Bible, from Chaucer and Shakespeare, and from Mark Twain. He has not, as John R. Milton had hoped, learned his proper relationship to his reader. Like the stonecutter

9 Ibid., p. 187-8.

10 Flora, op. cit., p. 21. 
(not sculptor) hero of his Milk of Wolves, he is content to carve out his works and to let his readers, particularly the sophisticated ones, learn their proper relationship to his works. Given time, this miracle may happen, for Manfred is a gifted storyteller who may be forgiven for what many critics seem to see as artistic faults.

Approaching a Manfred novel, the reader should first note that here is a distinct sensitivity at work. First, Manfred is unashamedly male, and he sees the male principle as the major creative force. He does not espouse the macho image for its own sake, however. Like the American Indian, or the American farmer, or like any people oriented to basics, he sees the regenerative force as both a blessing, and a threat. The male's function in the continuum is to sow the seed for the next generation-to guarantee the continuum. But the social animal needs to control that sex drive or he becomes, like the trickster in Indian myth and legend, a force that can destroy the society. Like the new-biologists, Manfred sees man as an aggressive predator. ${ }^{11}$ Second, Manfred is indeed rural, and this is not to say that he writes of the sensitive small-town youth who, like Sherwood Anderson's Winesburgians, must leave the crudeness and restrictions of the small midwestern towns for the culture of the cities. Manfred and his characters revel in the unsophisticated life. His characters may hate, at times, the work of the farm, for instance, but they take pride in the work, they take pride in fulfilling their responsibilities, they relate to the animal world with awe, curiosity, and humor, and seem crude in their expression of life. Especially the youthful heroes are torn between this sense of responsibility and their desire for freedom, just as they are torn between their sexual desires and the societal restrictions on them. Finally, Manfred's narrative perspective is distinctly his own. He makes little attempt to narrate with distance and objectivity. As writer, he often stands within the novel, blending his voice with those of the characters, moving into and away from them so that, at times, the reader has difficulty distinguishing between the voice of the character and Manfred's own voice. To the contemporary reader, this may be anathema, but it is Manfred's method. Such a method is less evident in his historical novels of the American West, which is one reason why most critics find these his most successful novels.

They are not, however, necessarily his most successful works. Manfred, as novelist, continues to improve, and that improvement comes more from a maturity of vision than anything else.

11 Manfred is an omnivorous reader and is particularly interested in the works of Robert Ardrey, Desmond Morris, Konrad Lorenz, Lionel Tiger, and other "new-biologists." 
The first of his last three novels, Milk of Wolves, was a long time waiting to be published. Because his editor had moved from one publishing house to another, there were complications. Milk of Wolves was too long and needed editing. Manfred was adamant. The maverick found himself a maverick publisher, and Milk of Wolves was finally published by the Avenue Victor Hugo Publishing Company in a columnized newspaper-type format, and was not, therefore, edited and cut by a New Yorker. The novel is the long, rambling story of Juhl Melander, who leaves his home after graduating from high school to find his way into the world of stonecutting. He leaves the village of Hackberry Run, his sister, and his mother, who had hoped he would continue as a blacksmith like his father. By the end of the novel, Juhl has moved full circle and is back in Hackberry Run to live in his father's house, where he will continue to cut stone. But it is the circle he has moved in that is important, even more than the coming home. The circle has been his life. How successful or satisfying that has been is reflected in his answer to his own self-questioning at the end of the novel, " 'Listen, if you were to tell me I had only one more minute to live, no more, I'd still say it was a great life. I don't regret one minute of it. All of it, the good with the bad, was wonderful. The whole river of it was worth having." "12

That whole river has been the life of a male artisan. He has seduced women, carved stone (or rather found the forms waiting to be released from the stone), married, fathered children, and battled the world to maintain his freedom on his own terms. As a stonecutter, he has thumbed his nose at the "culture" of the city. He has married one of the daughters of the rich, but he has remained the working man, the masculine hero who tests himself in the world of back-breaking toil as a stonecutter and lumberjack, and then has finally tested himself in the wilds on an island in the Lake of the Woods on the Canadian border. On the island, he returns to the primitive, and his statement at that point in the novel not only sums up Juhl Melander's attitudes about the male principle in art and life, but Frederick Manfred's as well.

The stronger the animal in man the better chance he had of getting the best of his blood into his civilized strategems. That was why he, Juhl Melander, once of the Cities and before that of Hackberry Run, had chosen to become a shacker on Big Wolfe Island. That he might, somehow, have the animal in him constricted and warped and made mean. Because he had done some mean low boorish things to his

12 Frederick Manfred, Milk of Wolves (Boston: Avenue Victor Hugo Publishing Company, 1976), p. 250. 
friends. Even villainous. Though of course that he'd remained the ruttish stud was perfectly all right. The genius in him was located in that. The whole point was to allow the genius stud in him to paw naturally for the white bird fluttering and singing just above him. ${ }^{13}$

The truth of the matter is that Juhl has acted boorishly and villainously not only to his friends, but to his wife and family as well. $\mathrm{He}$ has paid in guilt and suffering for what he has done, though he spends little time in complaint. The stud-genius, the artist-hero adapts well, however, to a primitive environment. He marries a young Indian girl, fathers a child, and finds his own "sacred" tree that puts him completely in touch with "place"-or the source of his being.

He spotted it across an open space and in the lowest part of the depression. It stood alone, apart from the others, as if the others had withdrawn in deference....

He went over and tried to put his arms around it. Lord God in heaven. . . . It was four foot through. It was the king all right. The monarch. The father of all red pines.

He pressed his cheek against one of the flakes of its tannish-red bark. The flake was as big as a plate. He placed his ear on the more solid part of the bark. With the top of the tree running in the strong wind he could hear profound anguishing sounds of live woods sliding over each other deep inside.

God.

In all his life he'd never heard anything like it. Heartwood music. Earth, without tongue, was here clearly humming a hymn to the sun. Or was the whole majestic tree the tongue? In any case, here at last was the true sound of a place. It came up out of the earth and rose through the vast trunk of the rooted monarch father. ${ }^{14}$

Although Juhl Melander has found "God"-for the exclamation in the preceding quotation is not only Juhl's surprised response to his discovery of the source of power through place, but it is also his recognition of that supreme power-he is not allowed to enjoy his idyllic retreat. He is defeated by man and nature. Starting out for civilization to try to stop the encroachment of government and real estate men who wish to develop the area into a park and tourist attraction, Juhl suddenly realizes that he has left his wife and son at the mercy of her incest-crazed brother. He returns immediately, only to find that the brother has already killed his wife. But his son is not dead. Juhl cuts into his own nipple to bring a flow of blood to nourish the child and, after days of feeding the child on blood, a tiny milk-sac develops in his breast. Juhl gradually develops a supply of

13 Ibid., p. 207.

14 Ibid., p. 185. 
milk to sustain his son. He has become both father and mother, incorporating both male and female principles in one body.

But he knows that he cannot withstand the combined efforts of state and local government, and he decides to return to civilization with his son. Crossing the lake, they are caught in a sudden storm and, though he ties his son to his back and manages to swim to the shore, his son has been drowned. At the end of the novel, he returns home but, as has already been indicated, with a sense of what his own life has been, and the power of it.

Such a simplified review can not, of course, give any suggestion of the depth or the complexity of the novel-its themes and its structure. Superficially, the artist-hero in working man's clothes and distrustful of the educated and the sophisticated may seem to resemble the artisthero of Ayn Rand's The Fountainhead, but the resemblance is only superficial. Juhl is sought after by women, he is the independent artist, he is a man of the working people, but he is also a boor and a villain, and Juhl himself, as well as the reader of the novel, is aware of his failings.

Nor does this hurried review of the novel indicate any of the "faults" that Manfred's critics will find with his artistry. As only one example, Manfred's treatment of sex is hardly conventional.

In an era when writers, both male and female, can delineate with great detail the sexual organs and the variety of sexual activities of both heterosexuals and homosexuals, Manfred remains something of an enigma. The problem is one of "voice," which has been mentioned earlier. Manfred as narrator, as well as his characters, views sex from a complicated and confused perspective. There is a certain air of Victorian puritanism and prudishness in the descriptions, and at the same time a rather adolescent romanticism that idealizes and spiritualizes sexual activity. Added to this is the crudity and boorishness of the farm youth who has grown up watching the coupling of mares and studs, bulls and heifers, boars and gilts-even roosters and hensand who has watched with natural curiosity, empathic delight, and even ribald but perhaps self-conscious humor. Here is neither the phenomenological descriptions of an Updike nor the "discovery" descriptions of Erica Jong who, in her own sophisticated way, always seems to write as though she has, standing on a peak in Darien, been the first to see the Pacific. In Manfred, there is, without apology, the early-twentieth-century Protestant, adolescent, barnyard views combined.

With all its literary "faults," however, Milk of Wolves is a strong 
novel, and it is particularly important for an understanding of Manfred's concepts of the artist and of Art.

Having completed Milk of Wolves, Manfred began work on a large autobiographical novel that once more would examine the world of his youth, but from a new perspective he had gained from his experiences with Juhl Melander. Somewhere during the composition of what would finally be Green Earth, Manfred felt the pull of another novel about the Indians and about the strange relationships between male and female, and the internal conflict of male and female within the individual. In a burst of energy and inspiration, Manfred completed this Indian novel, The Manly-Hearted Woman, which was published by Crown Publishers in 1975, the same year as the delayed publication of Milk of Wolves.

The Manly-Hearted Woman is a simply told, seemingly simple novel of two young Indians of opposite sexes whose lives cross momentarily but significantly. The first plot is the story of young Flat Warclub, who has never been on the warpath and who thus receives little respect from his own people. However, after a vision, he joins a war party which is leaving to help a sister band of Yankton Sioux against their mutual enemies, the Omaha. His vision is a tragic one. He is to lead his people to victory, but he will die in the battle, an accidental victim of one of his own men. Before he dies, however, the gods give him the right to "talk to" (or sleep with) any of the women of his sister tribe, for the band needs the regeneration of new seed. For a few days, he lives with a strange couple-both females, but husband and wife-while he "talks to" a variety of women, young and old. Finally, he is allowed to "talk to" only one of the couple, the wife Prettyhead. On the appointed day, he leads the war party against the Omaha and is killed as the gods had prophesied. His body is returned to the camp in honor.

The second plot is the story of Manly Heart, a girl who grows up in the Blue Mound band and whose early sexual experiments seem conventional except for her incestuous attraction for her brother, Stalk, although most of the Indian boys shame her because of her experiments with a youth named Hollow Horn. She is not only sexually precocious, she is also far too interested in the things boys do: riding horses, hunting, racing. Most important, she is fascinated by the concept of the Vision and its importance to the male. Her first marriage is to an aged widower, He Is Empty, and she changes from a "sitbeside" to a wife who sleeps with her husband and, in the process, rejuvenates him. At his death, however, she is left alone, and suitors 
once more begin to seek her out. Her second marriage is to a middleaged widower, Red Daybreak, who is a sadist. As they have intercourse, he chokes her. Finally, she overpowers him and then shames him. She divorces him, and once more she is alone. She tries to find happiness with a young lover, Sunny Day Walker, but he is too involved with himself, and his lovemaking is unsatisfactory. As she explains it, his song is too soon sung. She learns in these years that many women of the tribe are sexually unsatisfied.

One day, she goes alone from the village and has a vision. She is given a new secret name (Point from the Clouds), and she is told that she may live like a man, that she can go on hunts with the men, and that she may even take a wife. In short, she is now being allowed to be a man. Her helper is to be an ancient arrowhead that she must wear hanging between her breasts. She is also told that she will do great things and be renowned. As a woman, she continues to question the gods. "But, but, but," she questions, until the voice in the vision is almost exasperated. However, she returns to the village, takes a wife, and proceeds to live the life of a man with full acceptance by the men. She and Prettyhead, however, live in the lowest status-position in the village. It is in their tepee that Flat Warclub finds a temporary home.

On the day that Flat Warclub's helper tells him to stay with Prettyhead, Manly Heart, who is supposed to guard the horse herd, returns to the tepee despite the warning of her own helper. She questions her helper, disagrees with it, accuses the gods of being unfair, rationalizes her need to return to the tepee, and disobeys. As she leaves, the arrowhead drops to the ground, changes to a lizard, and disappears into a crevice. When she finds her way back to the tepee, she peeks beneath one side and watches Flat Warclub and Prettyhead in their lovemaking. She is amazed, almost thunderstruck, at the sight. She then guards them against any intrusion by others. She has fallen in love with the male-with Flat Warclub.

She has not only fallen in love with Flat Warclub, she has also found that they are closely linked in the other world, for she has found that his secret name, given him through his helper, is Stone from the Clouds. When the warriors bring his body back from the battle, she jealously assumes all responsibility for it. She does not allow the women with whom he has talked to touch the body, and she mourns alone. After a time, she returns to the village to live alone, divorcing Prettyhead. Once again, she must spend five days each month in the separation hut. Having become a woman again, she be- 
gins to menstruate. She no longer speaks to anyone in the tribe, and the rest of her life she is known as the Silent Woman.

Beneath this simple tale, however, lie many complexities. Before he dies, Flat Warclub realizes that he should have mated with Manly Heart, but it is too late, and the gods did not ordain it. By giving him the pleasures of his last few days, the gods have made him more aware of life, and thus of what he is about to lose. The sense of heroictragedy has been increased; and Flat Warclub becomes a martyr for the tribe. Further, the fates seem to have made the very battle in which he is killed almost unnecessary. When the Sioux ambush the enemy, the Omaha are starting on a peace mission to the Sioux. They have decided to share the buffalo run that has been the subject of the quarrel. Only the uncontrolled fury and sexual desire of Bitten Nose (an antagonist of Flat Warclub who had years ago killed his own brother) toward the beautiful maiden who is to be offered as a peace offering to the Sioux chief prevents the interruption of the gods' predictions. When the girl looks contemptuously at Bitten Nose's disfigured face, he pulls her from her horse and attempts to rape her. His actions, the actions of a true trickster character, start the battle. Thus, the novel deals with fratricide, with incest, with heroism, with spirituality, with life and death and sacrifice. It is perhaps Manfred's most compact, most tightly structured novel.

And it is told in the most simple of terms. On the surface, the novel reads like a warrior tale from one of the works of George Bird Grinnell, or like the simple novels of Indian life by James Willard Schultz. The rhythms ring true to Indian legends, and Manfred's sparing use of natural detail makes all of the story believable. Such a minor detail as the hide of a horse giving a "rippling shudder" immediately charges a scene with reality, and Manfred is as successful in describing the spirit world of the helpers as he is in evoking the realities of Indian life. Because of his restraint, his concern for structure, and his success in blending myth and reality, this will probably be viewed by most of his critics as his most successful novel.

Yet, as fine an achievement as it is, The Manly-Hearted Woman is not Manfred's best, for Manfred then turned to the completion of Green Earth, and this novel is Manfred's finest achievement to date. Green Earth is another autobiographical novel, in which Manfred returns once more to the Siouxland of his early years, the years preceding those described in The Primitive. The novel is divided into three books, each dedicated to a family component. The first book of 148 pages, "Lady of the House," is dedicated to "ALICE: mother;" the 
second, of 335 pages, "Lord of the Barnyard," to "Edward John, Floyd, John Garret, Abben Clarence, Henry Herman: brothers;" and the third, of 257 pages, "Angel Country," to "Henry Van Engen and Herman Van Engen: uncles." This is a more than appropriate dedication since Green Earth is a novel about family and its relationship to the land from which it gains a living, to its Christian and national heritage, and finally and particularly, that family's influence on the life of its children, in this case, of "Free Alfredson," the son of Ada Engelking Alfredson and Alfred Alfredson.

The novel begins:

It was the Sunday before Christmas, 1909. The Alfred Engelkings were having supper. It was a simple meal: rice with milk and brown sugar, black rye bread with butter, and green tea.

Almost from the first, Manfred has begun to detail the eating habits of the characters in the novel. And detail piles up in this novel to the point where many critics may find it obstructing the progression of the action. Yet, Green Earth, without the details of midwestern farm and country life of the teens and twenties would be, to some degree, like Irving's "The Legend of Sleepy Hollow" without the details of the Pennsylvania Dutch community. Detail in this novel does not impede as it does, say, in the novels of Thomas Wolfe. Detail establishes the way of life: the work, the way of living, the religious practices, the games, the attitudes, as well as the eating habits. The relationship of men and women to the farm animals, for example, and especially to the horses, is as important in this novel as it was to the people who farmed in Iowa in those days. The harness is described with an accuracy that recreates a historical period-and Manfred knows the difference between a checkrein and a crupper. The relationship that resulted from man's life with the horse is depicted not only in such scenes as planting and corn picking, but also in the relationship that made the death of a favorite buggy horse like a death in the family. In a technological age, in which a large segment of the population gets no closer to a cow or steer than a waxed carton of milk and a plastic-wrapped steak, such detail is necessary, for this novel is a hymn to an older way of life.

Most importantly, however, Manfred does not sentimentalize "the good old days." If readers feel nostalgia for those more pastoral days, that feeling will be conditioned by Manfred's delineation of the hardships of the way of life of that time. The back-breaking labor is there, and both men and women have their own variety of work. The plight of the renter, who moves from one farm to another, trying desperately 
to become a landowner, is part of the novel, but there are no Marxist overtones to the descriptions. The system is accepted by the farmers as their way of life. There are good and bad owners, and people live within a way of life without thinking about a "system," and the narrator does not impose an economic concept upon the materials. Manfred is not writing a political novel; he is presenting a human document.

That document certainly may appear to be flawed artistically. The novel begins with Ada Engelking and her first "romantic" courtship, and then moves on to a more mundane courtship by, and marriage to, Alfred Alfredson. Their first child, a male child named Alfred and nicknamed "Free," becomes the central character in the last two books. Once he is born, the focus of the book begins to shift to the problems of young Free and his attempt to adjust his own free and rebellious ego to his family and the society around him. Manfred, however, shifts focus carefully, almost as life itself shifts the focus from one generation to another. What is important is that the forces that operate in the first book remain as influences on the growing, developing boy. The individual, the novel seems to suggest, is shaped by the past and the environment into which he is born. Gradually, Free becomes the central character, but always in the background is the family and the way of life on the land, and the heritage of religious training.

Free grows, commits errors, feels guilt, and learns. His progress is neither a pilgrim's nor a hero's. He sees the world's hypocrisy and is made to feel his own. In short, Free Alfredson grows up, learning about the world that surrounds him, including the mysteries of sex. And throughout both Book Two and Book Three, there is the pervading sense of the shaping influences of his father and mother, and especially the mother. In particular, the mother is always there, and the novel ends with her death in 1929, on the same day as the death of Manfred's own mother.

Once more, with such a close autobiographical connection, there is the possibility of sentimentality, but Manfred carefully avoids it. The death scene is almost coldly realistic, with death coming as a matter of course after a detailed history of medical difficulties.

The novel is too long for a detailed analysis here of any of its parts. Unfortunately, for many critics Manfred's love of "things" will still be very much a part of this novel, his voice remains the voice that has disturbed many critics, and there will be those who will fault the structure of this novel. In some scenes, Manfred's taste may be questioned. He has not developed into a "sophisticated" writer, as some 
critics have hoped. What Manfred has done, however, has been to bring his "voice" into its most perfect expression of the people he writes about, and he has carved out a tremendously realistic novel about the development of a personality within the family context.

Manfred's growth as a novelist is most evident, however, in his vision of mankind. Much of the rebelliousness of his earlier novels, as in his attacks on hypocrisy and hypocrites, is muted in this fine novel. There is a mature vision of humanity in which divisions between good and bad are not so easily seen. There is a tolerance, a compassion, an understanding that values and celebrates life and seeks to reveal it in all its aspects, from its most ribald and humorous episodes to its most solemn. It is a vision different from that of Faulkner and Chaucer, but with the same involvement in mankind. It is important that critics learn to read Frederick Manfred in his own terms, for the rewards are great. Whether they do or not, Frederick Manfred will continue to write. He will, like Juhl Melander, in Milk of Wolves, keep trying to catch that "white bird fluttering and singing just above him." Just as Alfred Alfredson continued to farm, Manfred will continue to write, for that is his way of life, and that is his world. 


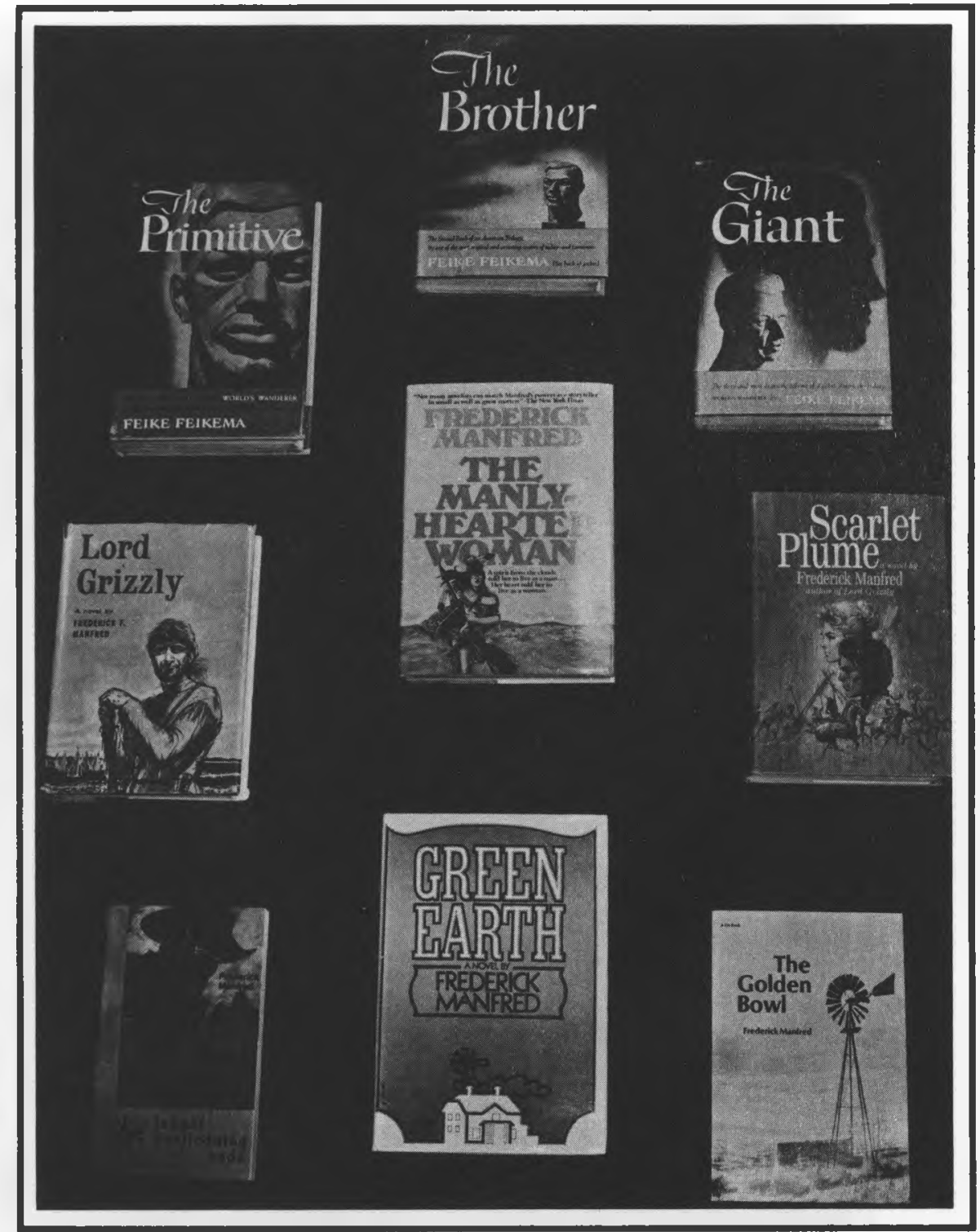

Among Frederick Manfred's most recent novels are The Manly-Hearted Woman (1976) and Green Earth (1977). Born near Doon, Iowa, Manfred has written extensively about the upper Midwest region, which he refers to as Siouxland. From the Iowa Authors Collection. 